\title{
Mycelium-producing Mushroom Calocybe indica (Milky Mushroom) as Bio-antagonist Against the Bacteria present in Marikina River
}

\author{
Vandon T. Borela ${ }^{1}$, Dhian Ashley DS. Apolinar ${ }^{2}$, Franz Weslei F. Cuachin ${ }^{3}$, \\ Laurence James R. Calañada ${ }^{4}$ \\ *Correspondence: borelavandon89@gmail.com \\ ${ }^{1}$ Teacher - Parang High School \\ ${ }^{234}$ Students - Parang High School
}

\begin{abstract}
Mushroom forming fungi are one of the nature's most powerful decomposers and degrades a wide variety of environmentally persistent pollutants and organic contaminants by secreting strong extra cellular enzymes due to their aggressive growth and biomass production. This study assesses the potential of Calocybe indica (Milky mushroom) as bio-antagonist against microorganism serves as pollutants on Marikina River through Heterotrophic plate count (HPC). The use of Calocybe indica (Milky mushroom) as the medium of mycoremediation effectively lessens the count of bacterial colonies in Marikina River's water by creating a bioantagonistic relationship with the bio-pollutants present on the water samples. Increasing the period of treatment and observation. Using of water samples from different depth from surface level down to aphotic region of the Marikina River. Identifying the strain of microorganisms present on the water. Using other mushroom to compare the potential of Calocybe indica to kill bio-pollutants should be done for the improvement of the study.
\end{abstract}

Keywords: Fungi, Mycoremediation, Bio-antagonism, Bio-pollutant

Received : October 21, 2020

Received in Revised: October 30, 2020

Accepted: November 1, 2020

\section{Introduction}

Nowadays, most cases of pollutants is not easily to determine, there are various ways to determine the status of the water. First, through chemical analysis which is very difficult and expensive. Second, through biological testing wherein it helps to determine different environmental factors affect various physiological processes. Thus, the biological testing, as a first stage in ecological monitoring system, enables reduce expenditures. In addition it makes it possible to detect the combined effect of a several pollutants (Gupta, R.K. and Doshi, A.2014)

Mushroom forming fungi are one of the nature's most powerful decomposers and degrades a wide variety of environmentally persistent pollutants and organic contaminants by secreting strong extra cellular enzymes due to their aggressive growth and biomass production (Packa, D. Wachowska, U. Wiwart, M. 2017). Nowadays, various species of mushroom formingfungi use for mycoremediation. Mycoremediation is a tool to remove the contaminants using different species of mushrooms. It effectiveness depends on the enzymes produced by the mushroom to remove the pollutant (Adenipekun C. O. and Lawal R. 2012).

In the study of Kumar G. et al (2016) they found out that Trichoderma sp. is an effectively bio-control to enhance the crop production without bringing any negative effects to the 
crops. In the study of Shekhar, S. Maurya, C. Srivastava, J. (2017) they used Oyster mushroom as mycofilter and removed the organic contaminants present in the wastewater by approximately $20 \%$ per cubic foot more effectively than mycofiltration by wood mulch alone. This mushroom produces a fungus-like bacterial colony called Mycelium, the vegetative part of a fungus or, consisting of a mass of branching, thread-like hyphae that shows a great potential in killing bacteria and using it as food for the mushroom. In the study of Landum M. C. et al (2015), fungi has an antagonistic activity by producing inhibitory volatile compounds that inhibit the growth of bacteria present on olive tree.

Calocybe indica (Milky mushroom) a tropical edible fungus, a protein source without cholesterol have an ability to maintain the blood cholesterol (Nita, B. 2002). Since same with Pleurotus $s p$. it is used for bioremediation but this mushroom is easy to cultivate, less investment very attractive fruiting body. Pleasing milk white color, long shelf life, more nutritious and less time to grow (Alam et al.,2008).

This study assess the potential of Calocybe indica (Milky mushroom) as bio-antagonist against microorganism serves as pollutants on Marikina River through Heterotrophic plate count (HPC).

The other factors contributing on the number of bacterial colony were not investigated in this study. Identifying the specific strains of bacteria were not included. This paper describes only the ability of the Calocybe indica as bio-antagonist to eliminate the bio-pollutants.

\section{Methods}

\section{The Research Design}

The method of research used by the researchers is experimental. It is a research design wherein the effects of a treatment on a variable is determined. The term experimental design refers to a plan for assigning experimental units to treatment condition.

\section{Statistical Analysis}

The researchers used the weighted mean count (WMC) is expressed as colony forming units (CFU) per mL sample (American Public Health Association 2012) and is calculated following the formula:

$$
\mathrm{WM}=\frac{\mathrm{n}}{(\mathrm{fa} \times 1)+(\mathrm{fb} x}
$$

Where: $\mathrm{n}$ - total number of colonies in all plates counted

$\mathrm{fa}$ - number of plates in the lowest dilution with countable colonies

$\mathrm{fb}$ - number of plates in the next higher dilution with countable colonies

\section{Gathering of Raw Materials}

The researchers collected the following materials: 3 aquarium, 3 aerator, 4 pairs of rubber gloves, 4 masks, 12 scouring pad, 6 six Liter water containers, cooler, marker, tape, plastic cover, milky mushroom (fruiting bag, sterilized glass bottle (for the water sampling), sticks, flour, scissors. 


\section{Setting of Materials}

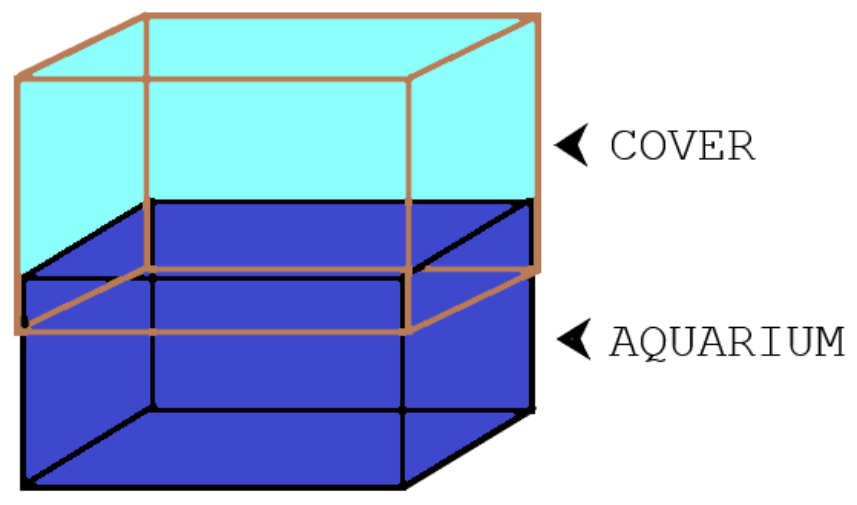

Figure 1. Set-up of Aquarium with water samples

The figure above shows the set-up of the materials wherein the water samples are placed in the aquarium. At the top of it, the Calocybe indica was placed.

\section{Collection of Water Samples}

The water samples were collected from three different sites of Marikina River namely: Barangka (S1), Sto. Nino (S2), Tumana (S3) on August 31, 2018 following the standard procedure in collecting water samples (Water Quality Monitoring Manual Volume 1).

\section{Water Analysis: Pre-treatment}

Heterotrophic Plate Count (HPC) were used to determine the number of bacterial colony. The water samples were serially diluted up to $10^{-5}$. One ml portion of the dilutions were pourplated in duplicates using Plate Count Agar. The plates were incubated at room temperature for 4 days and colonies were observed under Quebec colony counter (American Public Health Association 2012).

\section{Observation and Treatment}

The researchers observed the set-up every 24 hours for twelve days. The researchers put flour on the aquarium, it served as the food for the bacteria present on the water samples and measure the temperature of the water on each aquarium. The temperature readings were recorded on Table 1.

\section{Water Analysis: Post-Treatment}

Heterotrophic Plate Count (HPC) were used to determine the number of bacterial colony. The water samples were serially diluted up to $10^{-5}$. One $\mathrm{ml}$ portion of the dilutions were pourplated in duplicates using Plate Count Agar. The plates were incubated at room temperature for 4 days and colonies were observed under Quebec colony counter (American Public Health Association 2012).

\section{Results and Discussion}

Table 1. Daily Temperature of Water Samples

\begin{tabular}{|c|c|c|c|}
\hline \multirow{2}{*}{ DAYS } & $\begin{array}{c}\text { AQUARIUM 1 } \\
\text { (Site 1) }\end{array}$ & $\begin{array}{c}\text { AQUARIUM 2 } \\
\text { (Site 2) }\end{array}$ & $\begin{array}{c}\text { AQUARIUM 3 } \\
\text { (Site 3) }\end{array}$ \\
\cline { 2 - 4 } & Temperature ( $\left.{ }^{0} \mathrm{C}\right)$ & Temperature $\left(^{0} \mathrm{C}\right)$ & Temperature( $\left.{ }^{0} \mathrm{C}\right)$ \\
\hline
\end{tabular}




\begin{tabular}{|l|l|l|l|}
\hline 1 & 28 & 28 & 28 \\
\hline 2 & 28 & 29 & 29 \\
\hline 3 & 28 & 29 & 28 \\
\hline 4 & 29 & 28 & 29 \\
\hline 5 & 28 & 28 & 28 \\
\hline 6 & 28 & 28 & 28 \\
\hline 7 & 28 & 29 & 28 \\
\hline 8 & 28 & 28 & 29 \\
\hline 9 & 29 & 28 & 28 \\
\hline 10 & 29 & 28 & 28 \\
\hline 11 & 28 & 29 & 29 \\
\hline 12 & 28 & 28 & 28 \\
\hline
\end{tabular}

Source: Primary Data, 2020

Table 1 shows the temperature of water samples on three aquariums. The data shows that there is no tremendous change on the temperature of water during the twelve-day observation period.

Table 2. Heterotrophic Plate Count (HPC) of Environmental Water Sample: Pre-Treatment

\begin{tabular}{|c|c|c|c|c|c|c|}
\hline \multirow{2}{*}{$\begin{array}{c}\text { Sample } \\
\text { Code }\end{array}$} & \multicolumn{4}{|c|}{ Dilution } & HPC, CFU \\
\cline { 2 - 6 } & $10^{-1}$ & $10^{-2}$ & $10^{-3}$ & $10^{-4}$ & $10^{-5}$ & per ml \\
\hline S1 & TNTC $^{\mathrm{a}}$ & TNTC & $112^{\mathrm{b}} ; 88^{\mathrm{b}}$ & $16 ; 12$ & $2 ; 0$ & $1.0 \times 10^{5}$ \\
\hline S2 & TNTC & TNTC & $86^{\mathrm{b}} ; 68^{\mathrm{b}}$ & $16 ; 6$ & $0 ; 0$ & $7.7 \times 10^{4}$ \\
\hline S3 & TNTC & TNTC & $288^{\mathrm{b}} ; 248^{\mathrm{b}}$ & $26 ; 24$ & $3 ; 2$ & $2.7 \times 10^{5}$ \\
\hline
\end{tabular}

Source: Primary Data, 2020

a. Too numerous to count

b. Considered in the computation

c. Growth of spreader (bacteria that rapidly spread) observed; not counted

Table 2 shows the result of Heterotrophic plate count (HPC) test before the treatment period. It indicates that Samples 1, 2, 3 contained $1.0 \times 10^{5}, 7.7 \times 10^{4}, 2.7 \times 10^{5}$ CFU per $\mathrm{mL}$.

Table 3. Heterotrophic Plate Count (HPC) of Environmental Water Sample: Post Treatment

\begin{tabular}{|c|c|c|c|c|c|}
\hline \multirow{2}{*}{$\begin{array}{c}\text { Sample } \\
\text { Code }\end{array}$} & \multicolumn{4}{|c|}{ Dilution } & HPC, CFU \\
\cline { 2 - 5 } & $10^{0}$ & $10^{-1}$ & $10^{-2}$ & $10^{-3}$ & per ml \\
\hline S1 & TNTC $^{\mathrm{a}}$ & TNTC & $378 ; 336$ & $24 ; 35^{\mathrm{b}}$ & $3.5 \times 10^{4}$ \\
\hline S2 & TNTC & TNTC & Spr $^{\mathrm{c}} ; 141^{\mathrm{b}}$ & $30^{\mathrm{b}} ; 27$ & $1.6 \times 10^{4}$ \\
\hline S3 & TNTC & TNTC & $155^{\mathrm{b}} ; 122^{\mathrm{b}}$ & $33^{\mathrm{b}} ; 56^{\mathrm{b}}$ & $1.7 \times 10^{4}$ \\
\hline
\end{tabular}

Source: Primary Data, 2020

a. Too numerous to count

b. Considered in the computation

c. Growth of spreader (bacteria that rapidly spread) observed; not counted.

Table 3 shows the result of Heterotrophic Plate Count (HPC) test after the treatment period. It indicates that $\mathrm{S} 1, \mathrm{~S} 2$, and $\mathrm{S} 3$ contained $3.5 \times 10^{4}, 1.6 \times 10^{4}$, and $1.7 \times 10^{4} \mathrm{CFU}$ per $\mathrm{mL}$. 
Table 4. Comparison of Weighted Mean Count (WMC) of Heterotrophic Plate Count (HPC) Before and After the Treatment

\begin{tabular}{|c|c|c|c|}
\hline $\begin{array}{l}\text { Sample } \\
\text { Code }\end{array}$ & $\begin{array}{l}\text { Before the Treatment } \\
\text { (HPC, CFU per mL) }\end{array}$ & $\begin{array}{c}\text { After the Treatment } \\
\text { (HPC, CFU per mL) }\end{array}$ & Difference \\
\hline S1 & $1.0 \times 10^{5}$ & $3.5 \times 10^{4}$ & $6.5 \times 10^{-1}$ \\
\hline S2 & $7.7 \times 10^{4}$ & $1.6 \times 10^{4}$ & $6.1 \times 10^{-1}$ \\
\hline S3 & $2.7 \times 10^{5}$ & $1.7 \times 10^{4}$ & $2.53 \times 10^{-1}$ \\
\hline
\end{tabular}

Source: Primary Data, 2020

Table 4 shows the difference of weighted mean of Heterotrophic plate count of Water samples before and after the treatment period. It shows that, the Calocybe indica lessen siginifcantly the number of bacterial colonies in Sites 1 and 3.

Based from the data gathered there's no tremendous changed on the temperature of the water from Day 1 to Day 12 of treatment period. It means that the environment of the set-up were all well maintained. Based from the weighted mean count of Heterotrophic plate count before and after the treatment period it shows that the bacterial colony in Site 1: Barangka was lessen by $6.5 \times 10^{-1}$, while in Site 2: Sto. Niño was lessen by $6.1 \times 10^{-1}$, while on Site 3: Tumana was lessen by $2.53 \times 10^{-1}$. Among the three sites, the bio-pollutants in Site 1: Barangka were lessen. The results of the study showed that Calocybe indica (Milky mushroom) really served as an effective bio-antagonist to the bacteria present in Marikina River's Water. The heterotrophic plate count of the water samples unveiled that Calocybe indica (Milky mushroom) was not statistically significant in decreasing the amount or count of bacteria present in the water samples.

\section{Conclusion}

This study the use of Calocybe indica (Milky mushroom) as the medium of mycoremediation effectively lessen the count of bacterial colonies in Marikina River's water by creating a bioantagonistic relationship with the bio-pollutants present on the water samples. The researchers recommend the following for the improvement of the study. Increase the period of treatment and observation. Use water samples from different depth from surface level down to aphotic region of the Marikina River. Identify the strain of microorganisms present on the water. Use other mushroom to compare the potential of Calocybe indica to kill biopollutants.

\section{Acknowledgement}

The researchers would like to express their fullest gratitude to the persons who became part and helped in making this study possible namely; Mr. Vandon T. Borela for his guidance and help throughout the whole study, University of the Philippines - Natural Sciences Research Institute for the water analysis and recommendation of some methodologies that benefited the study. The researchers would also like to thank the unending support of the Parang High School community, Mrs. Edna Francisco and the faculty of the science department, and their beloved school head, Mr. Alberto Villamor.

\section{References}

Adenipekun, C. O., \& Lawal, R. (2012). Uses of mushrooms in bioremediation: A review. Biotechnology and Molecular Biology Reviews, 7(3), 62-68.

Alam, N., Amin, R., Khan, A., Ara, I., Shim, M. J., Lee, M. W., \& Lee, T. S. (2008). Nutritional analysis of cultivated mushrooms in Bangladesh-Pleurotus ostreatus, 
Pleurotus sajor-caju, Pleurotus florida and Calocybe indica. Mycobiology, 36(4), 228-232.

American Public Health Association, American Water Works Association, Water Pollution Control Federation, \& Water Environment Federation. (1915). Standard methods for the examination of water and wastewater (Vol. 2). American Public Health Association.

Department of Health (DOH). 2007. Philippine National Standards for Drinking Water. DOH, Manila

Gupta, R. K. (2014). Bioremediation of Heavy Metals through Cultivated and Wild Mushroom (Doctoral dissertation, MPUAT, Udaipur).

Kumar, G., Maharshi, A., Patel, J., Mukherjee, A., Singh, H. B., \& Sarma, B. K. (2017). Trichoderma: a potential fungal antagonist to control plant diseases. SATSA Mukhapatra-Annual Technical Issue, 21, 206-218.

Landum, M. C., do Rosário Félix, M., Alho, J., Garcia, R., Cabrita, M. J., Rei, F., \& Varanda, C. M. (2016). Antagonistic activity of fungi of Olea europaea L. against Colletotrichum acutatum. Microbiological research, 183, 100-108.

Nita, B. (2002) Handbook on mushrooms. Cultivation of straw mushroom, pp.s 4-61.

Wachowska, U., Packa, D., \& Wiwart, M. (2017). Microbial inhibition of Fusarium pathogens and biological modification of trichothecenes in cereal grains. Toxins, 9(12), 408.

Shekhar, S. Maurya, C. Srivastava, J. (2017) Remediation of Wastewater using Mushroom: Pleurotus ostreatus (Oyster Gill Mushroom). International Journal of Scientific \& Engineering Research. 8 (7), 352.

Taylor, A. W., \& Stamets, P. E. (2014). Implementing fungal cultivation in biofiltration systems-the past, present, and future of mycofiltration. National Proceedings: Forest and Conservation Nursery Associations-2013, 23.

Water Quality Monitoring Manual Volume 1. Manual on Ambient Water Quality Monitoring Environmental Management Bureau, Department of Environment and Natural Resources. https://water.emb.gov.ph/.../Water-Quality-Monitoring-Manual-Vol.-1ambient_14aug0 